\title{
Supply Chain Management in the Building Construction Industry: Linking Procurement Process Coordination, Market Orientation and Performance
}

\author{
Akmal Aini Othman ${ }^{1}$ \& Sofiah Abd Rahman ${ }^{1}$ \\ ${ }^{1}$ Department of Building, Faculty of Architecture, Planning and Surveying, \\ Universiti Technology MARA, 40450 Shah Alam Selangor Malaysia, \\ akmalainiothman@yahoo.com
}

\begin{abstract}
Supply chain (SC) is basically a network of firms involved in complex activities and multi processes. With such complexities, this management of interdependencies require to be coordinated to improve the performance of SC i.e. on flow of information, services, money and material. Various areas of supply chain management (SCM) have been explored by the researchers including supply chain coordination (SCC) and managing supplier relations. The initial part of this paper presents a conceptual discussion and framework of the link between market orientation, procurement process coordination and performance in the construction industry. It is supported with the result from a pilot case study in the building construction sector. The discussion from the pilot case study concentrates on the importance of market orientation and each activity in the procurement process coordination. Finding from this study illustrates that the importance of procurement process coordination in the construction industry slightly varies from manufacturing. While, several means of coordination could be adopted, information sharing and supply contract were demonstrated to be visible.
\end{abstract}

Keywords: Supply Chain Management, Market orientation, Procurement, performance \& construction

\section{Introduction}

With the increase of competition and technology enabling, many firms turning to supply chain management as a central part of strategic competence, which is believe would be able to create competitive advantage (Sheth \& Sharma, 1997). On the same line of thought firms are increasingly exploring ways to leverage their supply chains and particularly to systematically evaluating the role of suppliers in their activities. As cited by Kannan \& Tan (2006), leveraging supply chain allows the firms to exploit the capabilities, expertise, technologies, and efficiencies of their suppliers.This is supported 
by the claim made by Cousins, Lawson, \& Squire (2008), that close links between buyers and suppliers are increasingly cited as a critical differentiator of high and low performers in global supply chains.

Wisner (2003) in his study on SCM strategies and firm performance, described SCM as the integration of key business processes among a network of interdependent suppliers, manufacturers, distibution centers and retailers in order to improve the flow of goods, services, and information from original suppliers to final customers with the aims of reducing system wide costs while maintaining required service level. From here, several issues of SCM could be discussed further. Among those crucial issues are, SCM itself involves integration of business processes, consists of several players and the objectives is to improve the firm performance. Theoretically, the value chain is too complex to attain a full integration of all business processes within it, in order to gain the benefits offer by SCM (Tan, 2001). This leads to a second narrower perspective of SCM that is the integration of the various functional areas within an organisation to enhance the flow of goods from immediate strategic suppliers through manufacturing and distribution chain to the end user (Houlihan, 1987). With such perspective on SCM, it's not surprised that various areas of studies have been explored by the researchers in SCM. Along with are: managing supplier, managing process and activities in the supply chain (SC), integration and coordination of key processes, coverage in form of end-user to initial supplier and value creation. Apart from that, there are other means of classifying SCM literature, for instance it can be classified according to the integration, (i.e. internal chain, dyadic relationship, external chain and network suppliers and customers) among supply chain members (Harland, 1996; Tan, 2001).

\section{Procurement in SCM}

The discussion of this paper will concentrate on one of the processes in SCM, that is procurement or also known as supplier relationship management (SRM) from the perspective of dyadic relationship between the contractor (building construction) and the supplier, with the emphasis given on the coordination effort in this process. Although several attempts have been made to study this area, the study contributes to the development of knowledge by detailing the activities involved in procurement process instead of to analyse it in a general setting. This will allow greater 
understanding on the effect of each activity in procurement process coordination or SRM to performance in the Resource Based View (RBV) framework. Apart from that, this particular study will highight potential enablers such as market orientation that might play as an input for successful supply chain coordination (SCC).

Applying SCM to sectors such as manufacturing, retailing and distribution is not a new pheneomenon, where past studies in these areas have shown that SCM leads to improving a firm's competitiveness and profitability (Mentzer, 2001). However, adopting this concept into the construction industry is a new issue and it is a challenging due to the nature of the industry such as specialisation of work and the fragmentation of the overall process among supply chain members. For example, in comparing with other industries such as manufacturing, construction involved range of component parts with unique degrees of site or project requirements. With the immobility and size of the product in the construction, it requires to be assembled at the point of consumption (Gann, 1996). On top of that, it involves numbers of expert groups in a project like the engineers, designers and suppliers in completing a specific task or project. Thus it is not possible to assume a single firm would have the power or the ability to individually coordinate the whole supply chain, but every member can influence and be influenced by the whole supply chain (Isatto \& Formoso, 2006). Therefore, this particularly study would help to fill the gap.

Initially, this paper will discuss from a conceptual point of view, with some relevant previous studies are briefly analysed. Then, the results of pilot case study conducted in the building construction industry are presented.

\section{Construction Industry and Its Characteristics}

The construction industry can be divided into three broad sectors: (1) Building construction; (2) Heavy and civil engineering construction; (3) Specialty trade construction. Building construction itself consists of residential and non-residential such as commercial and industrial building (CIDB-Local Contractors, 2008).

It has been argued that this industry is a leader in term of outsourcing where it intensely relies on subcontractors and suppliers of building materials (Dubois \& Gadde, 2000). It is also been perceived as to be distinct itself from other industries, for example it is inherently a site-specific project-based activity (Cox \& Thompson, 1997; Dubois \& 
Gadde, 2002). With such discrete characteristic, it forced the industry to view the relationship between channel members from two perspectives. Like what have been pointed out by Welling \& Kaman (2001), SC partnership in construction industry can take place at the project level and firm level. This project level relationship is seen as temporary or short-term working arrangement that normally will hinder from innovation creation. Conversely, firm level relationship permits for long-term relationship building which may lead to the establishment of innovation for competitive advantage (Dubois \& Gadde, 2002). Besides these findings, more recent studies show that there are movements towards a relationship approach to the construction supply chains where it is shown that this industry engender specific relationship marketing (RM) practice in their project environment (Davis, 2008; Errasti, Beach, Oyarbide, \& Santos, 2007). As have been revealed by Errasti et.al. (2007), it is a matter of time before the ability to craft and sustain effective partnering relationships will become a precondition of doing business in the construction industry. They also added that, significant improvements may be feasible if contractors give attention to purchase volume on fewer suppliers and employ a partnership development process.

\section{Underlying Concepts}

Conceptual model of building procurement system in figure 1 consists of antecedent (market orientation); mediator (procurement process coordination) and consequence (performance). The model proposes that performance is influenced by the extent to which procurement process coordination (PPC) develops between contractor (buyer) and their supplier. The extent of PPC developed in this dyadic relationship depends on intensity of market orientation. 


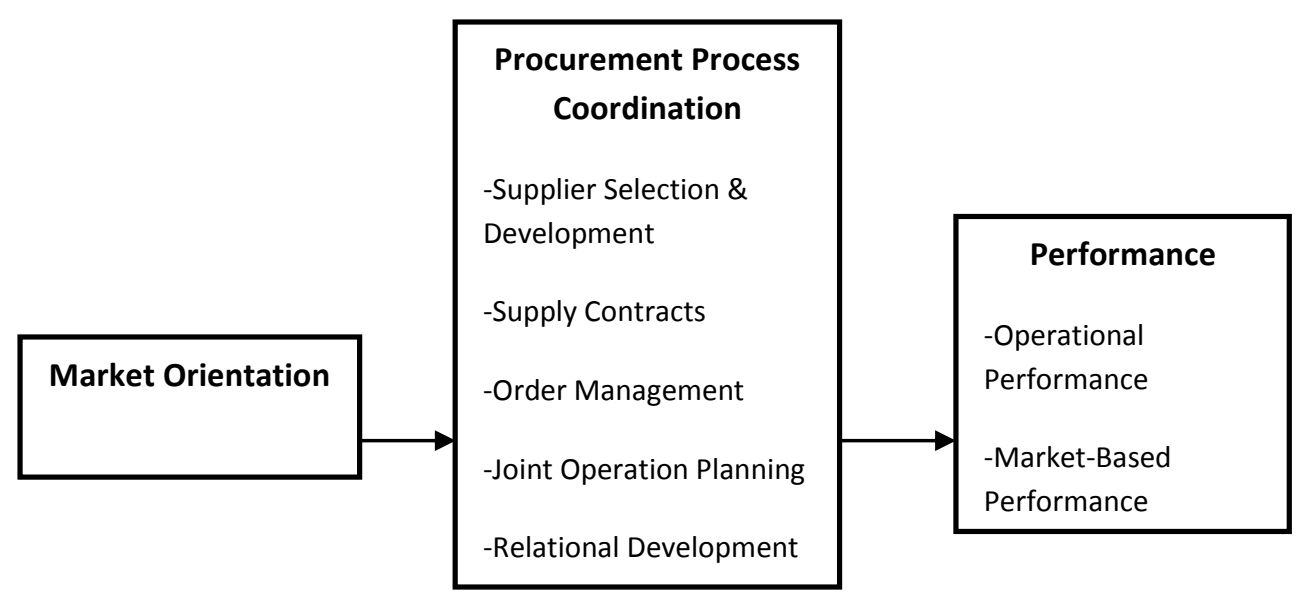

Figure 1: Linking Market Orientation with Performance via Procurement Process Coordination

\subsection{Procurement Process Coordination}

As mentioned in the earlier discussion, coordination has been recognised as a crucial SCM concept. This is supported by Ballou, Gilbert \& Mukherjee (2000), where coordination is perceived as a central lever of SCM. Even so, it may be difficult to come out with an exact meaning of coordination since there is no distinctive perspective on coordination. As nicely portrayed by Ashinder, Kanda, \& Deshmukh (2006) words such as integration, cooperation, collaboration and coordination is perceived as corresponding to each other and it is easily be regarded as part of SCC when used in the context of SC. In a nutshell, all are considered as components of coordination in which integration is referred as combining to an integral whole, collaboration (working jointly) while cooperation is viewed as joint operation (Arshinder, Kanda \& Deshmukh, 2008).

Due to its crucial contribution in the SC, several scholars have appeared to develop the concept of coordination in the SC, for instance they looked into the interfirm coordination process by focusing on several characteristics such as effective communication, information exchange, logistic synchronisation, incentive alignment and performance monitoring (Stank, Crum \& Arango, 1999; Lee, 2000; Simatupang, Wright \&Sridharan, 2002). Besides that, a comprehensive study that based on coordination theory by Arshinder, Kanda \& Deshmukh (2008) proposed a model of supply chain coordination index in which it consists of four selected coordination 
mechanism: (1) supply chain contract, (2) information technology, (3) information sharing, (4) joint decision making. The discussion of the above literature demonstrates that the tendency of previous research on SCC attempts to focus on three or four key elements of coordination. Among those elements, information sharing seems visible. Hence, it would be safe to claim that the basic dimension of coordination is the sharing of information between functions or firms. Indeed, information sharing provide visibility into supply chain process used to coordinate the flow of product (Simatupang, Sandroto, \& Lubis, 2004). These literatures somehow help in defining recent perspective of SCC as well as provide a guideline in measuring it.

In this proposed study, SCC is conceptualised as a process coordination capability. SC is basically a network of firms involved in complex activities and multi processes while SCM is increasingly being acknowledged as the integration of key business processes across SC. Thus the interdependencies need to be coordinated to enhance the performance of SC (Mentzer, 2001). Taking into account the whole processes of SCM in this study would be a perfect choice in order to portray the true picture of the phenomenon. However, due to the constraints, this proposed study will only focus on the procurement process or supplier relationship management process (SRM). It will concentrate in the procuring process of building construction sector. Procurement or SRM process is one of the processes in SCM process in which it is considered crucial and as an initiator to other processes (Arshinder et al., 2006; Lambert, Cooper \& Pagh, 1998; Xue, Li, Shen \& Wang, 2005). In the construction industry, cost of building materials accounts for $50 \%-60 \%$ of the total building costs while other costs such as labour contributes $30 \%$; heavy equipment $5 \%$ and construction management and supervision accounts for 15\% (Bartelsen \& Nielsen, 1997). Ironically, some studies in the construction industry explained that these resources, especially building materials are not sufficiently managed and in order to address this problem it has been suggested that there should be a close cooperation between the supply chain members (Bertelsen S., 1993; Bertelsen \& Nielsen, 1997).

Five sub-processes activities of procurement or SRM process that has been identified by Arshinder et. al. (2006) are: (1) Supplier selection and development; (2) Supplier contracts; (3) Order management; (4) Joint operation planning; (5) Relationship development. If right decision is taken to each, these five activities or sub 
processes are considered critical for the continuous improvement in performance (Arshinder et. al., 2006). For this proposed study, procurement process coordination (PPC) is conceptualised as the degree to which a focal firm (contractor) coordinated its procurement processes with its supply chain partner (supplier). In this respect, key to executing SCM depends on critical SC members and key business processes along which the partners are coordinated. These processes include procurement and other crucial processes and such SC related capabilities are widely acknowledged as source of competitive advantage, which leads to performance and this is consistent with Resource Based View (RBV) approach (Lamber, Cooper \& Pagh, 1998; Lynch, Keller \& Ozment 2000; Srivastava \& Fahey, 1999).

\subsection{Market Orientation}

Most widely used category in studying marketing resources, namely market orientation can be prescribed as a set of organisational behaviours devoted to the acquiring and utlising of market information for the purpose of achieving customer satisfaction (Narver \& Slater, 1990; Jaworski \& Kohli, 1993). Apart from viewing market orientation as a set of organisational behaviours it can also be regarded as culture where it comprises of customer orientation, competitor orientation and inter-functional coordination (Narver \& Slater, 1990). This dimension is one of the main concepts to marketing thought and practice and is related to firm performance (Greenly, 1995; Matanda \& Mavondo, 2001; Navar, Slater \& MacLachlan, 2004). It is perceived to be important factor to promote individual firms' coordinated activities inside and outside the firms to accomplish customer satisfaction at a profit (Min, 2001). This is consistent with the concept of SCM which stress on integrative philosophy to manage the total flow of distribution channel (Ellram \& Cooper, 1990).

\section{Methodology}

To support this paper, a pilot case study with six selected G7 building construction firms, through in-depth interviews was carried out. Based on Construction Industry Development Board (CIDB) Malaysia, contractors in Malaysia are graded into seven classes. G7 are those big contractors with value of project RM10 million and above (CIDB-Local Contractors, 2008). According to Yin, (1989) a case study is described as 
methodology based on interviews, which are used to examine technical aspects of an existing phenomenon with its real life context; when the boundaries between phenomenon and context are not clearly evident. This case study helps to demonstrate the consistency of the conceptual framework used in this study with the current practice in the construction industry. At the same time, it helps to test the validity of set of questions which are going to be used in the next step of the study, namely survey research. A set of questionnaire is used as an interview protocol, were asked to all key informants in the same order. As mentioned earlier, six representatives from building construction were selected to represent this sector. Since the questions are mostly related to strategic area and procurement related, the respondents were those who are at the managerial level and above with involvement in the purchasing or procurement. Due to confidential reasons, the company names are not revealed. They are only identified as Company A-F. Table 1 depicts the breakdown of the companies involved in this study.

The questions covered these two main areas:-

1. The importance of market orientation and its adoption in the building construction industry

2. The importance of procurement process coordination (supplier relationship) and its adoption in the building construction supply chain

Table 1: Company Types and Respondent Position

\begin{tabular}{|l|l|l|}
\hline \multicolumn{1}{|c|}{ Company } & \multicolumn{1}{|c|}{ Company Characteristics } & \multicolumn{1}{c|}{$\begin{array}{c}\text { Respondent/ } \\
\text { Interviewee Position }\end{array}$} \\
\hline Company A & $\begin{array}{l}\text { Local construction firm } \\
\text { Specialised in residential building }\end{array}$ & Project Manager \\
\hline Company B & $\begin{array}{l}\text { International construction firm } \\
\text { Involved in commercial and } \\
\text { residential building }\end{array}$ & $\begin{array}{l}\text { Project Manger / Quantity } \\
\text { Surveyor }\end{array}$ \\
\hline Company C & $\begin{array}{l}\text { Leading construction firm } \\
\text { Specialised in residential building }\end{array}$ & Operation Manager \\
\hline Company D & Multi-national construction firm & Administration Manager \\
\hline
\end{tabular}




\begin{tabular}{|l|l|l|}
\hline & $\begin{array}{l}\text { Involved in industrial and commercial } \\
\text { building }\end{array}$ & \\
\hline Company E & $\begin{array}{l}\text { Large corporate construction firm } \\
\text { Involved in commercial and } \\
\text { residential building }\end{array}$ & Quantity Surveyor \\
\hline Company F & $\begin{array}{l}\text { Local construction firm } \\
\text { Involved in industrial building }\end{array}$ & Director \\
\hline
\end{tabular}

\section{Finding and Discussion}

The research findings are discussed and presented in a sequence order based on the areas covered in the questionnaire.

\subsection{Procurement Process Coordination}

a) Buyer-supplier Relationship

From the feedback, it makes obvious that majority of the respondents indicate the understanding of supply chain management (SCM) is mainly related to the supply side, though in reality the concept of SCM encompasses the entire cycle of procurement, delivery and consumption (Mentzer, 2004). In relation to that, all respondents perceived relationship with supplier as essential in which this may lead to better operation with greater coordination, consistent with the findings of Ashinder, Kanda, \& Deshmukh (2006) and Simatupang, Sandroto, \& Lubis (2004). As mentioned by Company A, "we view our suppliers as team member. It is crucial for us to have good working relationship with suppliers since it may influence the price and quality of product to our clients". Company D and E however draw attention to other channel members, like for example the designer and the expert group besides the suppliers. This might be due to the nature of the project involved, more technical and complex, thus vastly need greater coordination with other channels members despite the suppliers.

\section{b) Bonding}

Although numerous studies portray adversarial relationship take place in this industry which largely due to its project based approach (Dubois \& Gadde, 2000; Dubois \& Gadde, 2002; Farmoso, Soibelman, De Cesare, \& Isatto, 2002;), the current study 
indicates that not all companies in this industry practice the same. In a nutshell, partnership is not temporary. There is a tendency towards long term bonding between the contractor and suppliers. This is consistent with what have been identified by Welling \& Kaman (2001), SC partnership in construction industry can take place at the project level and firm level. As been expressed by most companies "despite the fact that we involve with various projects, we prefer to deal with the same supplier. It makes our job easier since we are familiar with them and they know us well. Better deal is expected from such transaction". However, Company E did mention that, "while we prefer to deal with the same suppliers, certain requirements from the clients enforced us to work with other suppliers, we have no choice". Nonetheless, such findings lead us to another important issue, which is the element of trust. This long term partnership is seen as an essential instrument for building trust (Khalfan, McDermott, \& Swan, 2007)

\section{c) Trust and Cooperation}

Besides loyalty, there is a sign that element of trust appears in the relationship. Even so, the degrees of trust between the companies were varied. Company A, B and F for instance, said, "we have faith with our suppliers, they somehow helped us in getting the contract/tender. Though we have been dealing with them for quite sometimes, formal written contract do involve in our transaction. It is a company procedure somehow and sometimes it does help". Company A added that, their suppliers provide them more than just valuable information, at certain point they share plans and designs. On the other hand, Company D revealed that, it is a risk to be attached to a particular supplier. "Too much relying on specific supplier might put the company in jeopardise. They may simply leave us, and we are not of their intention. Formal agreement with appropriate written contract may help both parties to achieve stated objectives while at the same time continue good relationship". This mixed findings show that the concept of trust is somehow intricate and difficult to interpret. As what have been discussed in their paper, Moberg \& Speh (2003) and Yi, Tao, Li, \& El-Ansary (2008) highlighted the questionable of trust among channel members and how this element affect relationship and SCM. 


\section{d) Supplier Selection}

All respondents have no doubt with the elements of price and quality as pre-requisite to supplier selection. Even so, some of them do agree with other factors that should be taken into account in the selection process. Supplier's capability of information sharing, flexible contract and continuous improvement are also perceived to be essential in the selection of supplier by most respondents. "We wish to deal with those suppliers that have the credibility to offer us with better package. Their input such as price, to better decision is crucial to us. Suppliers that could offer greater flexibility in term of payment especially, is preferable. During hard time, with cash flow and time constraints, working with such suppliers is a blessed", revealed by most respondents. This claim highlights the importance of selecting the right supplier as been mentioned by (Kannan \& Tan, 2006). In other words, it emphasises on selecting supplier as source of value added where this may lead to success of buyer-supplier relationship and eventually firm performance. However, not all respondents appreciate "joint decision and plan" as important elements. This is consistent with the earlier finding on the confident level of the contractors towards their supplier.

\section{e) Supply Contract}

Not all respondents agree with the first statement on "no power domination between contractor and supplier in contract preparation'. Company A, B, C \& E admits that for certain products that are considered as standard products, less control made by both parties. Oppositely, when it comes to more complex and technical which require greater customisation and with only limited number of suppliers can offer, the tendency of imbalanced power is significant. As noted by Company D, "given that we involve with heavy and technical projects, the requirement for much specialised suppliers are essential. With their know-how, they normally have greater say than us, but since we have been working with them for quite sometimes, this barrier is able to handle fairly". In other issue, most respondents agree that contract helps their company and supplier to work towards desired goals. 


\section{f) Order Management}

Another mixed result from the respondents, in this section. The different opinions basically due to the nature of product or service involved. Since this study doesn't specify types of product or service offer by the supplier, a considerable difference of opinions can be seen from the feedback. For the record, questions used in this case study in principal were based from the literature which mainly comes from the manufacturing industry. In the construction industry, it was found that numerous types of suppliers involved in the channel system. As pointed out by Company D, "we deal with various kinds of suppliers in order to accomplish the task. These involved those who offer heavy equipment and machinery, labour, building material, service expertise etc." Company $\mathrm{F}$ who also involved in geotechnical works and instrumentation specialist reported that, "we have good contact with our supplier and working closely with them. In fact we are given exclusive right to carry supplier's name in marketing their instrument. While we have our own information system to connect and distribute project related information particularly between staffs in the organisation, we don't have any exclusive information system that links our company with the supplier. We don't really require such system to keep track with the order since it doesn't involve continuous transaction. Ordinary means of communication, such as email, telephone, and fax will be adequate".

On the contrary, Company $\mathrm{A}$ and $\mathrm{B}$ who involved with residential and commercial building construction and deal with material building suppliers have stressed on the importance of continuous connection with their suppliers. Company B explained that they do take the initiative to employ ordering system that could link their company with their building material supplier. "Despite the fact that it is difficult to create a holistic ordering system that could be linked with various parties and information, our company updates each other with the supplier by having a system that allows us to get access to the inventory level of building material. Just like manufacturing, the issue of inventory management is crucial since it contribute to cost creation. We may not that good in adapting Just-in-Time (JIT) concept as to compare with manufacturer; nonetheless we do take this into account in our inventory managerial process". 


\section{g) Joint Decision Planning}

As compared to other activities, joint decision is shown to be a bit selective in its adaptation by majority of the respondents. Despite the fact that information sharing is considered crucial, joint decision with the suppliers on certain aspects isn't well accepted. For example, Company $\mathrm{C}$ said, "we agree that joint decision is vital in order to coordinate process between our company and supplier, however, not all of the areas of joint decision could be easily accepted". Company B noted that, "to make sure that required items reach to the right destination at the right time etc., we do participate in decision collaboration with our supplier. Joint decision in scheduling delivering and inventory planning are normal. Building materials products such as cement, sand and concrete blocks are basically standard items, thus decision on product and process design is largely depend on the supplier".

\subsection{Market Orientation}

Irrespective of types of company, all approached respondents agree that client satisfaction is the priority. As mentioned by one of the respondents, in order to stand out of the crowd, company needs to offer some of value to the client. "All contractors can build building, but not all contractors can deliver it at the right time and required quality. Thus, serving customer at its best through closed monitoring their requirement and better than competitors is the answer to this game". Such claimed correspond with those findings by Greenly (1995); Matanda \& Mavondo (2001); Navar, Slater \& MacLachlan (2004) that market orientated practices lead to certain result such as improvement in its operation performance.

Apart from that, most respondents highlighted the competitiveness of the market has pushed the construction companies to be more aggressive, in the sense they are more alert to the market requirement and proactive in action. The requirement of the ISO standard by the CIDB is perceived by majority of the respondents as a driving force to the G7 companies to be more systematic in running their business. "Though it is painful to attain the ISO standard, the reward from the adoption seems to be fruitful to the company as a whole. Indirectly we are forced to work in an organised manner. We are forced to plan ahead, to keep our records accordingly etc." Such feedback on ISO gives an indication that enforcement on certain established system may indirectly 
encourage the contractors to be more responsive to the requirements of the market. As mentioned earlier, this systematic approach proposed by ISO is seen to be parallel with market orientation that emphasises on customer satisfaction and inter-functional coordination. This apparently may contribute to better performance to the operation of a firm and eventually is seen to encourage industry efficiency. As such, there is a need to persist with this ISO enforcement.

The above discussion demonstrates that the adoption of market orientation is not only restricted to certain industries, like for instance manufacturing and services, but construction industry, particularly the big players are increasingly adopting such orientation in facing the competitive environment.

Table 2, 3 and 4 indicate inputs from six selected companies.

Table 2: Input on Procurement Process Coordination from Different Companies

\begin{tabular}{|c|c|c|c|c|c|}
\hline \multirow{2}{*}{$\begin{array}{l}\text { Compan } \\
\mathbf{y}\end{array}$} & \multicolumn{5}{|c|}{ Procurement Process Coordination } \\
\hline & $\begin{array}{l}\text { Supplier } \\
\text { Selection }\end{array}$ & $\begin{array}{l}\text { Supply } \\
\text { Contract }\end{array}$ & $\begin{array}{l}\text { Order } \\
\text { Managemen } \\
\text { t }\end{array}$ & $\begin{array}{l}\text { Joint } \\
\text { Decision } \\
\text { Planning }\end{array}$ & $\begin{array}{l}\text { Relationship } \\
\text { Developmen } \\
\text { t }\end{array}$ \\
\hline $\begin{array}{l}\text { Company } \\
\text { A }\end{array}$ & $\begin{array}{l}\text { Importance } \\
\text { of } \\
\text { informatio } \\
\mathrm{n} \text { sharing } \\
\text { and } \\
\text { flexible } \\
\text { contract in } \\
\text { supplier } \\
\text { selection. }\end{array}$ & $\begin{array}{l}\text { Contract is } \\
\text { considered } \\
\text { important } \\
\text { to meet } \\
\text { defined } \\
\text { goal and } \\
\text { prefer to } \\
\text { have some } \\
\text { rooms of } \\
\text { flexibility } \\
\text { in certain } \\
\text { areas }\end{array}$ & $\begin{array}{l}\text { No online } \\
\text { system } \\
\text { connecting } \\
\text { with supplier } \\
\text { but able to } \\
\text { keep track } \\
\text { with the } \\
\text { inventory } \\
\text { level and } \\
\text { ordering } \\
\text { information. }\end{array}$ & $\begin{array}{l}\text { Involved in } \\
\text { join } \\
\text { decision } \\
\text { planning } \\
\text { with } \\
\text { supplier. } \\
\text { Areas such } \\
\text { as building } \\
\text { material } \\
\text { demand } \\
\text { forecasting, } \\
\text { and } \\
\text { scheduling } \\
\text { activities } \\
\text { are } \\
\text { important. }\end{array}$ & $\begin{array}{l}\text { Dealing with } \\
\text { the same } \\
\text { suppliers for } \\
\text { different } \\
\text { projects } \\
\text { Have long } \\
\text { term } \\
\text { commitment } \\
\text { and trust } \\
\text { each other }\end{array}$ \\
\hline $\begin{array}{l}\text { Company } \\
\text { B }\end{array}$ & $\begin{array}{l}\text { Importance } \\
\text { of } \\
\text { informatio } \\
\mathrm{n} \text { sharing } \\
\text { and } \\
\text { flexible } \\
\text { contract in }\end{array}$ & $\begin{array}{l}\text { Contracts } \\
\text { are not } \\
\text { rigid with } \\
\text { some } \\
\text { changes } \\
\text { could be } \\
\text { made due }\end{array}$ & $\begin{array}{l}\text { Connected } \\
\text { with the } \\
\text { supplier via } \\
\text { online } \\
\text { ordering } \\
\text { information } \\
\text { system. }\end{array}$ & $\begin{array}{l}\text { Joint } \\
\text { decision } \\
\text { planning } \\
\text { limited to } \\
\text { scheduling } \\
\text { delivery } \\
\text { activities }\end{array}$ & $\begin{array}{l}\text { Continuously } \\
\text { working with } \\
\text { same } \\
\text { suppliers } \\
\text { regardless of } \\
\text { project } \\
\text { awarded. }\end{array}$ \\
\hline
\end{tabular}




\begin{tabular}{|c|c|c|c|c|c|}
\hline & $\begin{array}{l}\text { the } \\
\text { selection } \\
\text { of supplier }\end{array}$ & $\begin{array}{l}\text { to certain } \\
\text { constraints } \\
\text { important } \\
\text { imool. }\end{array}$ & $\begin{array}{l}\text { Different } \\
\text { departments } \\
\text { in the } \\
\text { organisation } \\
\text { are } \\
\text { connected to } \\
\text { ordering } \\
\text { information } \\
\text { system too. }\end{array}$ & only & $\begin{array}{l}\text { This long } \\
\text { term } \\
\text { commitment } \\
\text { leads to trust } \\
\text { and risk } \\
\text { sharing. }\end{array}$ \\
\hline $\begin{array}{l}\text { Company } \\
\text { C }\end{array}$ & $\begin{array}{l}\text { Favour to } \\
\text { work with } \\
\text { suppliers } \\
\text { that can } \\
\text { provide } \\
\text { input for } \\
\text { better } \\
\text { decision. } \\
\text { Payment } \\
\text { flexibility } \\
\text { is critical } \\
\text { too. }\end{array}$ & $\begin{array}{l}\text { Contracts } \\
\text { are } \\
\text { planned } \\
\text { jointly but } \\
\text { sometimes } \\
\text { due to } \\
\text { some } \\
\text { restraints, } \\
\text { supplier } \\
\text { will do the } \\
\text { lead. }\end{array}$ & $\begin{array}{l}\text { The } \\
\text { company and } \\
\text { suppliers } \\
\text { have access } \\
\text { to building } \\
\text { material } \\
\text { order } \\
\text { tracking and } \\
\text { updating } \\
\text { each other } \\
\text { continuously. }\end{array}$ & $\begin{array}{l}\text { Participate } \\
\text { in certain } \\
\text { activities of } \\
\text { joint } \\
\text { planning } \\
\text { with } \\
\text { suppliers } \\
\text { but a bit } \\
\text { worried on } \\
\text { the risk } \\
\text { involved } \\
\text { due to } \\
\text { information } \\
\text { leakage to } \\
\text { the } \\
\text { competitors }\end{array}$ & $\begin{array}{l}\text { Dealing with } \\
\text { the same } \\
\text { suppliers for } \\
\text { different } \\
\text { projects } \\
\text { Do trust each } \\
\text { other but at } \\
\text { the same } \\
\text { time aware } \\
\text { with the risk } \\
\text { involved. }\end{array}$ \\
\hline $\begin{array}{l}\text { Company } \\
\text { D }\end{array}$ & $\begin{array}{l}\text { Quite } \\
\text { selective in } \\
\text { supplier } \\
\text { selection } \\
\text { and choose } \\
\text { to work } \\
\text { with those } \\
\text { who could } \\
\text { provide } \\
\text { better offer } \\
\text { than other } \\
\text { suppliers. }\end{array}$ & $\begin{array}{l}\text { Contracts } \\
\text { are } \\
\text { perceived } \\
\text { as } \\
\text { important } \\
\text { in } \\
\text { managing } \\
\text { suppliers. } \\
\text { Any } \\
\text { changes in } \\
\text { price } \\
\text { should be } \\
\text { made } \\
\text { agree by } \\
\text { both } \\
\text { parties. }\end{array}$ & $\begin{array}{l}\text { Various } \\
\text { departments } \\
\text { in the } \\
\text { organisation } \\
\text { are } \\
\text { connected to } \\
\text { the ordering } \\
\text { information } \\
\text { system. } \\
\text { Order } \\
\text { tracking on } \\
\text { building } \\
\text { material is } \\
\text { accessible } \\
\text { for both the } \\
\text { company and } \\
\text { supplier. }\end{array}$ & $\begin{array}{l}\text { Joint } \\
\text { decisions } \\
\text { are } \\
\text { considered } \\
\text { crucial, but } \\
\text { at certain } \\
\text { point, } \\
\text { there's no } \\
\text { need to } \\
\text { have the } \\
\text { supplier to } \\
\text { be involved } \\
\text { partly } \\
\text { because of } \\
\text { time } \\
\text { constraints } \\
\text { and the } \\
\text { company } \\
\text { have more } \\
\text { say. }\end{array}$ & $\begin{array}{l}\text { Admit that } \\
\text { not only } \\
\text { supplier } \\
\text { relationship } \\
\text { is crucial, but } \\
\text { other supply } \\
\text { chain } \\
\text { members are } \\
\text { important as } \\
\text { well in } \\
\text { achieving } \\
\text { defined } \\
\text { goals. Quite } \\
\text { sceptical in } \\
\text { dealing with } \\
\text { limited } \\
\text { number of } \\
\text { suppliers due } \\
\text { to certain } \\
\text { risk. }\end{array}$ \\
\hline
\end{tabular}




\begin{tabular}{|c|c|c|c|c|c|}
\hline $\begin{array}{l}\text { Company } \\
\text { E }\end{array}$ & $\begin{array}{l}\text { Suppliers } \\
\text { who could } \\
\text { offer more } \\
\text { value } \\
\text { added } \\
\text { service } \\
\text { such as } \\
\text { informatio } \\
\mathrm{n} \text { sharing } \\
\text { and } \\
\text { expertise } \\
\text { are more } \\
\text { preferable. }\end{array}$ & $\begin{array}{l}\text { Contracts } \\
\text { are used to } \\
\text { guide } \\
\text { channel } \\
\text { members. } \\
\text { They } \\
\text { permit } \\
\text { changes } \\
\text { which due } \\
\text { to } \\
\text { unexpecte } \\
\text { d events. }\end{array}$ & $\begin{array}{l}\text { Suppliers } \\
\text { continuously } \\
\text { maintain } \\
\text { adequate } \\
\text { level of } \\
\text { inventory } \\
\text { based on } \\
\text { information } \\
\text { provided } \\
\text { through } \\
\text { order } \\
\text { tracking } \\
\text { system. }\end{array}$ & $\begin{array}{l}\text { Involved in } \\
\text { join } \\
\text { scheduling } \\
\text { activities } \\
\text { but lack in } \\
\text { other area. }\end{array}$ & $\begin{array}{l}\text { Prefer to deal } \\
\text { with the } \\
\text { same } \\
\text { suppliers but } \\
\text { sometimes, } \\
\text { due to client } \\
\text { requirement } \\
\text { limits } \\
\text { continuous } \\
\text { relationship }\end{array}$ \\
\hline $\begin{array}{l}\text { Company } \\
\text { F }\end{array}$ & $\begin{array}{l}\text { Informatio } \\
\mathrm{n} \text { sharing is } \\
\text { crucial. } \\
\text { Supplier is } \\
\text { also } \\
\text { expected to } \\
\text { actively } \\
\text { involve in } \\
\text { join } \\
\text { activities } \\
\text { such as } \\
\text { promotion. }\end{array}$ & $\begin{array}{l}\text { Have long } \\
\text { term } \\
\text { contract. } \\
\text { Carry } \\
\text { supplier } \\
\text { name. }\end{array}$ & $\begin{array}{l}\text { The need for } \\
\text { continuous } \\
\text { ordering } \\
\text { online } \\
\text { system is } \\
\text { limited due } \\
\text { to the nature } \\
\text { of product } \\
\text { provided by } \\
\text { the supplier. } \\
\text { However, } \\
\text { inter- } \\
\text { departmental } \\
\text { information } \\
\text { system is } \\
\text { well } \\
\text { connected. }\end{array}$ & $\begin{array}{l}\text { Supplier } \\
\text { involve in } \\
\text { join } \\
\text { scheduling } \\
\text { activities, } \\
\text { forecasting } \\
\text { and even } \\
\text { promotion. } \\
\text { Limited } \\
\text { involvemen } \\
\mathrm{t} \text { of the } \\
\text { supplier in } \\
\text { product and } \\
\text { process } \\
\text { design }\end{array}$ & $\begin{array}{l}\text { Dealing with } \\
\text { the same } \\
\text { suppliers for } \\
\text { different } \\
\text { projects } \\
\text { Have long } \\
\text { term } \\
\text { commitment } \\
\text { and trust } \\
\text { each other }\end{array}$ \\
\hline
\end{tabular}

Table 3: Input on Market Orientation from Different Companies

\begin{tabular}{|l|l|}
\hline Company & Market Orientation \\
\hline Company A & $\begin{array}{l}\text { Stress the importance of client and supplier satisfaction and } \\
\text { monitoring competitor actions. }\end{array}$ \\
\hline Company B & $\begin{array}{l}\text { Client satisfaction is important. The needs to monitor competitors' } \\
\text { actions. }\end{array}$ \\
\hline Company C & $\begin{array}{l}\text { Client satisfaction is important and rapidly respond to competitors' } \\
\text { action }\end{array}$ \\
\hline Company D & $\begin{array}{l}\text { Competitive market requires proactive action in managing clients } \\
\text { and suppliers }\end{array}$ \\
\hline Company E & $\begin{array}{l}\text { Client satisfaction is priority with high degree of inter } \\
\text { departmental connection }\end{array}$ \\
\hline Company F & $\begin{array}{l}\text { Respond to clients needs and good relationship with channel } \\
\text { members is crucial }\end{array}$ \\
\hline
\end{tabular}


Table 4: Input on Effect to Performance from Different Companies

\begin{tabular}{|l|l|}
\hline Company & Performance \\
\hline Company A & $\begin{array}{l}\text { Having good relationship with high degree of cooperation with } \\
\text { channel members such as supplier would encourage better decision. } \\
\text { Such relationship encourages knowledge transfer which is perceived } \\
\text { could influence the operational performance especially. }\end{array}$ \\
\hline Company B & $\begin{array}{l}\text { Good connection with suppliers is perceived to enhance operational } \\
\text { performance and eventually to meet the market needs. This helps in } \\
\text { meeting product specification and cost reduction. }\end{array}$ \\
\hline Company C & $\begin{array}{l}\text { Flexible contract through supplier relationship building permit the } \\
\text { company to meet required performance like meeting the deadline, } \\
\text { reduction of defective rate and ultimately client satisfaction. }\end{array}$ \\
\hline Company D & $\begin{array}{l}\text { Greater flexible contract allows unforeseen forces to be handled } \\
\text { effectively. Hardly faced problem in meeting the timeline and product } \\
\text { specification. Numbers of client complaints are considered low. }\end{array}$ \\
\hline Company E & $\begin{array}{l}\text { With appropriate selection of suppliers, this will help the company to } \\
\text { work effectively with suppliers and gain advantage through this } \\
\text { relationship. Information sharing with greater understanding between } \\
\text { firms leads to efficient outcome such as meeting clients' needs and } \\
\text { reduce defective rate... }\end{array}$ \\
\hline Company F & $\begin{array}{l}\text { Benefits of relationship building with supplier are perceived to } \\
\text { influence the cost and quality of a project. Input generation through } \\
\text { joint decision between firms allow better decision and eventually } \\
\text { influence performance. }\end{array}$ \\
\hline
\end{tabular}

\section{Way Forward}

From this study it may be observed that coordination in the procurement process or SRM is perceived to add value to the construction industry, particularly in the building sector. It has been shown to influence performance mainly in the operational and market-based aspect. This is attained through coordination effort of various activities in the procurement process and continuous commitment that eventually engenders trust, and result to satisfaction. Marketing orientation that stress on client focus and coordinated approach too has been perceived as crucial and was found to be widely adopted by the contractors especially when time are tough. In other words, competitive forces do shape the industry to be more focus on crucial elements such as client needs and managing business in more efficient and effective manner. This brief explanation on the general findings of the present study leads to several pertinent points that require attention for further investigation. These include those crucial elements related to the current study which embrace the issue of coordination, trust, commitment, IT and degree of procurement activities. 
Further result from the above pilot case study indicates that there is willingness and effort moving towards meaningful business relationship with the supplier in this industry. This is parallel with recent literature in construction industry by Davis (2008), demonstrated that players in this construction supply chain, namely the upstream and downstream are in the direction of relationship marketing (RM) approach, with emphasising on trust, commitment and long-term relationship. As mentioned by Davis (2008) in his discussion on a study carried out by Green, Newcombe, William, Fernie, \& Weller (2002), this relationship-based supply chain approches have a tendency to generate knowledge benefits which is crucial in a competitive advantage building. Thus it is vital for a contractor to understand the essential of relationship building and its contribution to the firm performance. As such further investigation is required to examine how these elements of relationship building in the construction supply chain could be developed further. This is consistent with the previous reports which called for industry improvement via ‘Rethinking Construction’ (Egan, 1998; Latham, 1994). Apart from that, there is a need to investigate further the issue of trust and commitment in this relationship building since both are considered crucial and were found to be inticate. No doubt that various studies have been carried out in these areas (Bennett \& Gabriel, 2001; Eriksson \& Laan, 2007; Khalfan, McDermott, \& Swan, 2007; Kingshott \& Pecotich, 2007; Yi, Tao, Li, \& El-Ansary, 2008) notably in the mainstream research, nonetheless, adopting research technique from successful disciplines into this field (construction) is considered critical.

Another interesting finding that requires bringing to light is the degree of importance of each activity in the procurement process to the firm performance. While most respondents agree with their involvement in various activities in procurement process, the level of importance varies. This study does not mirrored to the study in the manufacturing industry which conducted by Ashinder, Kanda, \& Deshmukh (2006) where the involvement of the contractor and supplier are more towards information sharing and contract management. Such result echoed to the finding on limited adoption of information technology (IT) in this industry. It was observed that IT adoption is relatively restricted, particularly when dealing with inter firm connection between contractor and the supplier. Since IT has been highligted by many researchers as an input to improve inter-orgnanisational coordination (Co, Patuwo, \& Hu, 1998; McAfee, 
2002; Sanders, 2008; Small, 1999), there is a need to look into this issue in a more comprehensive manner. Further research should address questions on what are the barries that may hinder and factors that may drive to the adoption of IT principally in this construction sector. Answers to such questions are seen to be critical in the adoption of this coordination concept and ultimately to the performance improvement of this industry.

Although relationship development with supplier was identified to be apparent, not all activities in the procurement process work the same. In this study, joint operation planning is seen to be reserved in its adoption with limited collaboration activities take place between the channel members in the procurement process. Only selected areas of collaboration come into picture where scheduling deliving activities and price forecasting seem to be noticeable. However, these collaboration activities mainly occur in the procuring process for building materials. Such result indicates the relevancy on the proposed procurement process concept in managing building materials. Thus there is a requirement for further research to be carried out in this sector which may focusing on the procurement process of building material

Besides those findings, it has been shown that the benefits of coordination in the procurement process can be grasp, but the degree of importance of each activity is perceived as varies in this construction industry. Despite the fact that most activities in the procurement process coordination are perceived to contribute to better firm performance, the degree of importance of each activity and the mechanism of coordination adopted in this construction industry may influence the result. Hence it is crucial for the management to understand which of these activities of procurement process coordination contribute the most to firm performance and which are lacking in this industry. In this study, it has been shown that there is lacked of adoption of collaboration effort such as joint decision making as compare to supplier relationship development and supply contract. Since this paper is noticeably only a conceptual paper with some supportive input from a pilot case study. Much work need to be done through empirical testing for further confirmation to be revealed. Such understanding may help the management in term of why and where to place the effort and to invest resources, apart from what to expect as reasonable return on this investment. 


\section{References}

Ashinder, Kanda, A., \& Deshmukh, S. (2006). A coordination-based Perspective on the Procurement Process in the Supply Chain. Int. J. Value Chain Management , 1 (2), 117-138.

Ashinder, Kanda, A., \& Deshmukh, S. (2008). Supply Chain Coordination: Perspectives, Empirical Studies and Research Directions. Int. J. Production Economics , 115, 316-335.

Ballou, R., Gilbert, S., \& Mukherjee, A. (2000). New Managerial Challenges from Supply Chain Opportunities. Industrial Marketing Management , 29 (1), 7-18.

Bennett, R., \& Gabriel, H. (2001). Reputation, Trust and Supplier Commitment: The Case of Shipping Company/Seaport Relation. Journal of Business and Industrial Marketing , 16 (6), 424-438.

Bertelsen, S. (1993). Building Logistics-Material Management in the Building Process. The Danish Ministry of Housing and Building.

Bertelsen, S., \& Nielsen, J. (1997). Just-In-Time Logistics in the Supply of Building Materials. 1st International Conference on Construction Industry Development: Building the Future Together. Singapore.

Cannon, J. P., \& Perreault JR, W. D. (1999). Buyer-Seller Relatonship in Business Marketing. Journal of Marketing Research , 36 (4), 439-460.

Carr, A. S., \& Pearson, J. N. (1999). Strategically Managed Buyer-Supplier Relationships and Performance Outcomes. Journal of Operations Management, 17 (5), 497-519.

CIDB-Local Contractors. (2008, November). Retrieved November 2008, from CIDB Malaysia Official Portal: CIDB Malaysia Official Portal

Co, H., Patuwo, E., \& Hu, M. (1998). The Human Factor in Advanced Manufacturing TechnologyAdoption: An Empirical Analysis. International Journal of Operations and Production Management , 18 (1), 87-106.

Cousins, P. D., Lawson, B., \& Squire, B. (2008). Performance Measurement in Strategic Buyer-Supplier Relationship: The Mediating Role of Socialization Mechanisms. International Journal of Operations \& Production Management, 28 (3), 238-258. 
Cox, A., \& Thompson, I. (1997). 'Fit for Purpose' Contractual Relations: Determining a Theoretical Framework for Construction Projects. European Journal of Purchasing and Supply Management , 3, 127-135.

Davis, P. R. (2008). A Relationship Approach to Construction Supply Chains. Industrial Management \& Data Systems, 108 (3), 310-327.

Dubois, A., \& Gadde, L.-E. (2000). Supply Strategy and Network Effects - Purchasing Behaviour in the Construction Industry. European Journal of Purchasing \& Supply Management , 6, 207-215.

Dubois, A., \& Gadde, L.-E. (2002). The Construction Industry as a Loosely Coupled System:

Implications for Productivity and Innovation. Construction Management and Economics , 20, 621-631.

Egan, J. (1998). Rethinking Construction. London: Department of the Environment, Transport and the REgions and HMSO.

Ellram, L. M., \& Cooper, M. C. (1990). Supply Chain Management Partnerships, and the Shipper-Third Party Relationship. International Journal of Logistics Management, 1 (2), 1-10.

Eriksson, P. E., \& Laan, A. (2007). Procurement Effects in Trust and Control in ClientContractor Relationships. Engineering, Construction and Architectural Management , 14 (4), 387-399.

Errasti, A., Beach, R., Oyarbide, A., \& Santos, J. (2007). The Process for Developing Partnerships with Subcontractors in the Construction Industry: An Empirical Study. International Journal of Project Management , 25, 250-256.

Farmoso, C. T., Soibelman, L., De Cesare, C., \& Isatto, E. (2002). Material Waste in Building Industry: Main Causes and Prevention. Journal of Construction Engineering and Management, 128 (4 (August)), 316-325.

Gann, D. M. (1996). Construction as a Manufacturing Process? Similarities and Differences Between Industrialized Housing and Car Production in Japan. Construction Management and Economics , 14, 437-450.

Green, S., Newcombe, R., William, M., Fernie, S., \& Weller, S. (2002). Supply Chain Management: a Contextual Analysis of Aerospace and Construction. Procurement Systems \& Technology Transfer: CIBW92 Procurement Systems 
Symposium, Departmment of Civil Engineering University of West Indies (pp. 245-61). Trinidad: Lewis, T.M. (Ed).

Greenly, G. E. (1995). Market Orientation and Company Performance: Empirical Evidence from UK Companies. British Journal of Management , 16 (1), 1-13.

Harland, C. M. (1996). Supply Chain Management: Relationships, Chains and Networks. British Academy of Management , 7 ((Special Issue)), S63-S80.

Houlihan, J. B. (1987). International Supply Chain Management. International Journal of Physical Distribution and Materials Management , 17 (2), 51-66.

Isatto, E. L., \& Formoso, C. T. (2006). The Inter-Firm Coordination of the Construction Project Supply Chain. Proceedings IGLC-14, July 2006, (pp. 293-308). Santiago Chile.

Jaworski, B. J., \& Kohli, A. K. (1993). Market Orientation: Antecedents and Consequences. Journal of Marketing , 57 (3), 53-70.

Kannan, V. R., \& Tan, K. C. (2006). Buyer-Supplier Relationships: The Impact of Supplier Selection and Buyer-Supplier Engagement on Relationship and Firm Performance. International Journal of Physical Distribution \& Logistics Management, 36 (10), 755-775.

Khalfan, M. M., McDermott, P., \& Swan, W. (2007). Building Trust in Construction Project. Supply Chain Management: An International Journal , 12 (6), 385391.

Kingshott, R. P., \& Pecotich, A. (2007). The Impact of Psychological Contracts on Trust and Commitment in Supplier-Distributor Relationships. European Journal of Marketing , 41 (9/10), 1053-1072.

Lambert, D. M., Cooper, M. C., \& Pagh, J. D. (1998). Supply Chain Management: Implementation Issues and Research Opportunities. International Journal of Logistics Management, 9 (2), 141-58.

Latham, M. (1994). Construction the Team. London: HMSO.

Lee, H. L. (2000). Creating Value Through Supply Chain Integration. Supply Chain Management Review , 4 (4), 30-36.

Lynch, D. F., Keller, S. B., \& Ozment, J. (2000). The Effects of Logistics Capabilities \& Strategy on Firm Performance. Journal of Business Logistics , 21 (2), 47-67. 
Matanda, M., \& Mavondo, F. (2001). The Effect of Market Orientation and Supply Chain Efficiency on Business Performance. Australian and New Zealand Marketing Academy(ANZMAC). Albany.

McAfee, A. (2002). The Impact of Enterprise Information Technology Adoption on Operational Performance: An Empirical Investigation. Production and Operations Management , 11 (1), 33-53.

Mentzer, J. T. (2004). Fundamentals of Supply Chain Management: Twelve Drivers of Competitive Advantage. Sage Publications.

Mentzer, J. T. (2001). Supply Chain Management. Sage Publications Inc.

Min, S. H. (2001). Supply Chain Management. In J. T. Mentzer (Ed.). Sage Publications Inc.

Moberg, C. R., \& Speh, T. W. (2003). Evaluating the Relationship between Questionable Business Practices and the Strength of Supply Chain Relationship. Journal of Business Logistics , 24 (2), 1-19.

Narver, J. C., \& Slater, S. R. (1990). The Effect of a Market Orientation on Business Performance. Journal of Marketing , 54, 20-35.

Naver, J. C., Slater, S. R., \& MacLachlan, D. L. (2004). Responsive and Proactive Market Orientation and New Product Success. The Journal of Product Innovation Management , 21 (5), 334-347.

Sanders, N. R. (2008). Pattern of Information Technology Use: The Impact on BuyerSupplier Coordination and Performance. Journal of Operation Management, 26, 349-367.

Sheth, J. N., \& Sharma, A. (1997). Supplier Relationships: Emerging Issues and Challenges. Industrial Marketing Management , 26, 91-100.

Simatupang, T. M., Sandroto, I. V., \& Lubis, S. H. (2004). Supply Chain Coordination in a Fashion Firm. Supply Chain Management , 9 (3), 256-268.

Simatupang, T. M., Wright, A. C., \& Sridharan, R. (2002). The Knowledge of Coordination for Supply Chain Integration. Business Process Management Journal , 8 (3), 289-308.

Small, M. (1999). Assessing Manufacturing Performance: An Advanced Manufacturing Technology Porfolio Perspective. Industrial Management and Data Systems , 99 (6), 256-267. 
Srivastava, R. K., \& Fahey, L. (1999). Marketing Business Processes and Shareholder Value: An Organizationally Embedded View of Marketing Activities and the Discipline of Marketing. Journal of Marketing , 63 (Special Issue), 168-179.

Stank, T., Crum, M., \& Arango, M. (1999). Benefits of the Interfirm Coordination in Food Industry Supply Chain. Journal of Business Logistics , 20 (2), 21-42.

Tan, K. C. (2001). A Framework of Supply Chain Management Literature. European Journal of Purchasing \& Supply Management , 7, 39-48.

Tan, K. C., Handfield, V. R., \& Ghoh, S. (1999). Supply Chain Management: An Empirical Study of its Impact on Performanc. International Journal of Operations and Production Management , 19 (10), 1034-1052.

Welling, D. T., \& Kaman, D.-J. F. (2001). Vertical Cooperation in the Construction Industry: Size Does Matter. Journal of Supply Chain Management , 37 (4), 2833.

Wisner, J. D. (2003). A Structural Equation Model of Supply Chain Management Strategies and Firm Performance. Journal of Business Logistics , 24 (1), 1-26.

Xue, X., Li, X., Shen, Q., \& Wang, Y. (2005). An Agent-based Framework for Supply Chain Coordination in Construction. Automation in Construction , 14, 413430.

Yi, L., Tao, L., Li, Y., \& El-Ansary, A. I. (2008). The Impact of a Distributor's Trust in a Supplier and Use of Control Mechanisms on Relational Value Creation in Marketing Channels. Journal of Business \& Industrial Marketing , 23 (1), 1222.

Yin, R. (1989). Applied Social Research Method Series. Case Study Research - Design and Methods , 34. 